\title{
10 White workers and the unravelling of racial citizenship in late apartheid South Africa
}

\author{
Danelle van Zyl-Hermann
}

\section{Introduction}

Historians of South Africa recognise the 1970s as an important turning point for apartheid. The growth and stability which had characterised the post-war economy was replaced by stagnation and inflation which would last until the regime's demise in 1994. Rising living costs and growing unemployment hit the disenfranchised African population hardest, fermenting enduring discontents about the race-based exploitation and subjugation suffered under white rule. In January 1973, strikes erupted in the factories around Durban as African workers demanded wage increases and industrial representation. Within weeks, strike action had spread across South Africa's industrial centres and by March, 160 work stoppages involving 60,000 workers had taken place. The strikes were typically of short duration as employers scrambled to respond to wage demands and instituted factory-based negotiations structures. Workers returned to the factories - but the collective power and new confidence of the semi-skilled African labour force operating the country's most important industry had been forcefully demonstrated. When from June 1976 violent clashes between schoolchildren and police in Soweto sparked revolt throughout South Africa's black townships, the possibility of African workers throwing their weight behind community-based demands for rights and political freedom threatened political and economic instability the country could ill afford. ${ }^{1}$

These developments provoked a crucial shift in the white regime's rhetoric and strategies of dominance. Even as the government set out to sharpen its repressive tactics - pumping money into defence and counterinsurgency, flooding black townships with military vehicles and young white conscripts, and expanding the powers of the security apparatus - the realisation dawned that stability and economic growth could not be restored through repression alone. ${ }^{2}$ Reform was needed.

The industrial arena was the obvious starting point for forestalling a full-blown crisis. In July 1977, Prime MinisterVorster appointed the Wiehahn Commission of Inquiry into Labour Legislation to investigate and make recommendations regarding all existing labour legislation in South Africa. The Commission was requested to submit interim reports 'in view of the urgency of the matter'. ${ }^{3}$ 
After nation-wide consultation with stakeholders from industry, organised labour, government and civil society, the Commission tabled its first and most important report in Parliament on Labour Day 1979. In a historic move, it recommended the dismantling of the apartheid labour dispensation, starting with the abolition of race-based job reservation and the legal recognition of African trade unions. These proposals envisioned, for the first time in South Africa's history, an integrated system of labour relations in which African workers would be given a seat at the table in labour negotiations and industrial councils. ${ }^{4}$

These recommendations were celebrated - not least of all internationally as major reforms. ${ }^{5}$ But local labour observers, and scholars subsequently, were quick to point out the limitations and underlying political objectives of the new labour dispensation. Centrally, the reforms sought to forestall the radical politicisation of the African labour force. In order to gain legal recognition and admittance to the industrial conciliation system, African unions were required to register with the newly created Department of Manpower, and subject their activities and finances to its scrutiny. In this way, the state sought to gain control over the unions, prohibiting direct association with political movements, donations from foreign anti-apartheid organisations or liberation movements in exile, and restricting labour mobilisation to the workplace so workers would not unite with other groups to challenge white rule. In this way, labour relations would be depoliticised. Moreover, the state initially sought to grant labour rights only to Africans permanently residing in the cities, while continuing to exclude the bulk of the black labour force seen as migrant workers from the black homelands. This new politics of inclusion, it was hoped, would give socalled urban Africans a stake in the system, secure their allegiance to the state granting them industrial citizenship, and consequently see them relinquish any further claims to full citizenship. ${ }^{6}$ In this sense, labour reform foreshadowed later constitutional changes, which sought, in turn, to co-opt South Africa's coloured and Indian minorities by granting them the political power to elect their own representatives and preside over certain circumscribed community affairs. This aimed to imbue the system with some much-needed legitimacy while still leaving overall white political dominance in place. ${ }^{7}$

White capital, too, stood to benefit from labour reform. While the conditions created by racial oppression had long suited capitalist interests, the economic slowdown of the 1970s saw the constraints of racial capitalism shift to outweigh its benefits: the exploitation of the majority black population not only inhibited the development of wider domestic markets but increasingly led to labour unrest. Moreover, racial discrimination obstructed the effective utilisation of labour. While awareness of the political and economic hazards created by racial capitalism came unevenly to South African capital, the business community had become a major advocate of reform by the time Wiehahn was appointed. ${ }^{8}$ From this point of view, the Commission's recommendation to scrap race-based job reservation would finally remove statutory obstructions to the reorganisation of labour, while industrial citizenship would deliver an acquiescent and more productive black labour force - and hence get the economy back on track. 
Scholars have since labelled these reforms "neo-apartheid" attempts to 'remodel thoroughly the foundations of white supremacy'; a "scheme" to 'share power without losing control'; ${ }^{10}$ a new politics of inclusion and exclusion, reformulating the terms on which certain "non-whites" participated in the state in order to bolster the legitimacy of the apartheid regime and gain control over the elements challenging it. ${ }^{11}$ In his analysis of the Wiehahn inquiry, Ashforth argues that reform constituted a redefinition or reimagining of the status of urban Africans, redefining them as not in the first place black, but as workers. This served to neutralise the political nature of their demands by focusing on labour rights. ${ }^{12}$

There is a larger literature outside South Africa on labour struggles and the redefinition of citizenship in the period leading up to decolonisation and majority rule. From the mid-1930s, French and British colonial regimes were confronted with increasingly forceful strike action and political movements amongst African workers. Consequently, colonial bureaucrats were forced to reimagine African labour and implement reforms in order to pre-empt labour crises with the potential to spill over into other spheres. Cooper explains how both 'British and French governments, in quite different ways, were trying to construct some kind of junior citizenship through which colonized people could partake of some, but not all, of the qualities of a metropolitan citizen'. ${ }^{13}$ These reconceptions would provide new legitimacy for colonial governments by incorporating labour into the post-war colonial system, while at the same time serving to regain control over African workers and to separate them from other groups with which they might unite to challenge colonial rule. Ultimately, this project of reimagining labour in such a way as to serve colonial interests failed as African labour organisations seized upon the discourses and redefinitions colonial officials were employing to claim rights and entitlements. ${ }^{14}$

In South Africa, decades later, labour reforms, like later constitutional reforms, served only to highlight Africans' continued political disenfranchisement and exclusion from full citizenship. And like their British and French colonial counterparts earlier in the century, black workers seized upon the new, albeit restricted, opportunities accorded by the legalisation of African labour organisation to mobilise resistance to white domination and claim full political rights. The proliferation of black trade unions from the late 1970s led to the formation of the Congress of South African Trade Unions (COSATU) in December 1985, which united over half a million black workers around the 'inseparability of shop-floor struggles and the broader political struggle'. ${ }^{15}$ COSATU took up a central role in the liberation struggle, thus proving decisively that state efforts 'to prevent trade unions from becoming agents for political transformation in South Africa had failed'. ${ }^{16}$

But absent from such considerations of reform-era South Africa are the experiences of the country's white industrial workforce. By the 1970s, some 400,000 white workers -29 per cent of the economically active white population of 1.4 million - were organised in trade unions. ${ }^{17} \mathrm{~A}$ substantial number of Afrikaners, in particular, remained in blue-collar occupations throughout the 
apartheid period, with 38 per cent working in blue-collar positions in $1970 .^{18}$ Although they certainly formed a minority of the labour force in primary and secondary industry, these white workers represented a crucial and historically powerful part of the workforce: they held the majority of supervisory and skilled jobs, as well as a significant proportion of semi-skilled positions, and effectively controlled the organised labour movement. Within the racial state, they were also the only workers with political rights.

These white workers had long reaped the benefits of race-based citizenship in the workplace and South African society at large. Yet scholarship on the lateapartheid period examining the conflicts and interests of the white state, capital and African workers has not taken account of the implications of reform for white workers in the industrial arena. Focusing on evidence brought before the Wiehahn inquiry, this chapter investigates white workers' response to efforts to placate black political demands and accommodate the shifting needs of capital by reimagining black workers' status. This provides new insights into issues of race, labour and citizenship in the late apartheid racial state.

\section{White workers in South Africa's racial order}

Although racially discriminatory practices had long characterised colonial South Africa, the mineral revolution of the second half of the nineteenth century effected the formation of racial capitalism and the racial state. White workers' material and subjective position was closely bound up with these processes. White miners saw both the Africans, alongside whom they worked, and the mine owners, eager to substitute them for less expensive labour, as threats to their position. ${ }^{19}$ These conditions, argues Krikler, were crucial to the racial formation of white working-class identity. In the presence of a large black labour force, white workers defined themselves in relation to 'that which they were not': rightless, exploited and racially despised blacks. Threats to their position thus raised interconnected fears of being thrust into poverty and of losing their racial identity. ${ }^{20}$

Efforts to replace white with black labour led to violent industrial conflict in the first two decades of the twentieth century, with white workers demanding race-based protection from capital's efforts to undermine the colour bar. ${ }^{21}$ In 1924, the Industrial Conciliation Act established an industrial relations system through which employers' organisations and trade unions could negotiate the peaceful resolution of industrial conflicts. The Act expressly barred Africans from these structures by excluding them from joining trade unions. Thus, unionised workers - whites, but also other minority race groups - were given the power to negotiate for the racial allocation of the most favoured jobs and working conditions. In subsequent years, governments expanded social security and job opportunities reserved for whites, and legislated for the payment of higher "civilised labour" wages to unskilled white workers. ${ }^{22}$ These developments are understood as serving to co-opt white labour into formal, statecontrolled structures of power. Thus emerged the outlines of a moral economy 
in which political elites bestowed protection and privilege on white workers in exchange for their political support. ${ }^{23}$ This served to diffuse class tensions within the white population, binding white workers into a social order which emphasised their racial identity and elevated them on this basis.

This process was given a particular ethnic character when the National Party (NP) came to power in 1948. Described as a "class alliance" between Afrikaner petty bourgeois, working classes and farmers ${ }^{24}$ the NP rose to popularity with its calls for greater racial segregation and "apartheid" in the wake of growing concerns about poor "whiteism" during the Great Depression, and the acceleration of African urbanisation as South Africa's manufacturing industry grew during the Second World War. Once in power, the NP set out to bolster racial privilege in the labour arena. ${ }^{25}$ Its 1956 Industrial Conciliation Act extended existing provisions for race-based job reservation and forbade the registration of new multiracial trade unions. Existing multiracial unions were ordered to split into separate branches for white, coloured and Indian workers, with only whites serving on union executives. These measures secured white leadership of the organised labour movement while weakening the bargaining position of other workers included in the industrial relations system. ${ }^{26}$ Key sections of organised white labour, such as mining production workers, enjoyed ready access to government ministers and party executives ${ }^{27}$ reflecting the moral economy of mutual obligation and reciprocity between white workers and the dominant classes of the apartheid state.

These labour determinations formed part of the NP's broader efforts to statutorily impose a social hierarchy in which racial identity determined every aspect of political, economic and social life and formed the basis of inclusion and exclusion in the racial state. The NP's policy of separate development entrenched the correlation between race and citizenship. ${ }^{28}$ The 1950 Population Registration Act divided the South African population by race, subdivided, in turn, into ostensibly distinct ethnic units, and the 1959 Promotion of Bantu Self-Government Act determined that separate black ethnic "nations" would be led to "full development" and "full authority" in their "own areas". ${ }^{29}$ This scheme sought to split the black majority into a collection of ethnic minorities, depriving those in the rural areas of their South African citizenship through self-government, and thus securing white political dominance in the Republic. It made no provision for Africans residing in South Africa's "white" cities, or for the country's coloured and Indian communities. ${ }^{30}$ This policy, explains Dubow, saw apartheid evolve "from the pronouncement of white domination ... to an elaborate and obfuscatory ideology of "multi-national" development'. ${ }^{31}$

In 1970s, the Bantu Homelands Citizenship Act sought to expedite this process. Africans residing in the cities were now also deemed to belong to a specific ethnic homeland, and hence deprived of their South African citizenship. The Bantu Homelands Constitution Act, passed in 1971, placed all homelands on track to political, executive and judicial self-government. In the course of the next seven years, eight homelands achieved this status. In this way, Pretoria sought to further safeguard white power by engineering an artificial white 
majority. ${ }^{32}$ By 1978, Minister of Plural Relations Connie Mulder could confidently state in Parliament that

[i]f our policy is taken to its logical conclusion as far as black people are concerned, there will be not one black man with South African citizenship. [...] Every black man in South Africa will eventually be accommodated in some independent new state in this honourable way and there will no longer be a moral obligation on this Parliament to accommodate these people. ${ }^{33}$

By the 1970s, therefore, the South African government was more forcefully than ever promoting a politics which 'embedded ideas of differential nationhood and citizenship' based on race. ${ }^{34}$

In the labour arena, racial citizenship translated into established privileges and protection for white workers. This is not to say, however, that all white workers supported this system fully. Factionalism along racial and ideological lines had long characterised the South African labour movement. While the NP's exploitation of white working-class fears, as well as the legislation it implemented once in power, had been quite successful in suppressing socialist tendencies amongst organised labour, different views remained on the desirability of a multiracial labour movement. The 1956 Act's restrictions on multiracial unions consequently saw organised labour fracture into two main camps. The Trade Union Council of South Africa (TUCSA) represented mostly multiracial industrial unions and craft unions in the commercial and manufacturing sectors. Membership was restricted to registered unions, but TUCSA maintained liaison ties with African workers. The South African Confederation of Labour (SACLA), in contrast, represented the racially exclusive industrial unions in older industries such as mining, steelworks and the railways, as well as a number of predominantly Afrikaner craft unions in construction and state employment. The NP-supporting SACLA opposed multiracial industrial unions and any form of African labour organisation. ${ }^{35}$

By the time the Wiehahn Commission was appointed in 1977, SACLA represented some 200,000 white workers, or about 31 per cent of the organised labour force. TUCSA, in turn, represented around 223,000 workers, of whom the majority were coloured, some were Indian, and about 58,000 were white. As per statutory determinations, TUCSA was white-led, even though the complexion of its leaders was representative of only 27 per cent of its members. ${ }^{36}$

This chapter focuses on SACLA and its affiliated unions' response to the prospect of labour reform - not only because SACLA was the most substantial representative body of white workers at the time, but also because a focus on this section of organised labour offers the opportunity to investigate how those white workers historically most invested in South Africa's racial order responded to the prospect of labour reform. Given existing scholarly understandings of how white workers contributed to the making of the racial state, and how their identity formation and material position was intricately bound 
up with the conditions of its making, this chapter seeks to investigate how these workers responded to the possibility of reform as the unmaking of racial privilege in the labour arena. Faced with the crescendo of African resistance and the changing needs of capital in the late 1970s, how did white workers articulate their identities and claims? What does this reveal about the politics between dominant and subaltern white classes at a time when the very basis of white supremacy was being reformulated? And what can this tell us about race, labour and citizenship at this crucial historical juncture?

This chapter addresses these questions by examining SACLA workers' testimony before and participation in the Wiehahn Commission of Inquiry into Labour Legislation. It draws on the Commission's extensive documentary archive, comprising written representations and comments received from various stakeholders, as well as some 10,000 pages of verbatim minutes from the oral testimony and deliberation meetings of the Commission, conducted between 1977 and $1980 .{ }^{37}$ This evidence offers new insights as to the class conflicts produced within white society in the political economic context characterising the late apartheid era, and into the entanglement of race, labour and citizenship in South Africa. This contributes to the intellectual project of rethinking white societies in Southern Africa by probing the shifting fortunes of white subalterns vis-à-vis changes in the structure of capitalism and the nature of the state under white minority rule, moving towards a deeper understanding of the manner in which class position coloured racial standing in the racial state.

\section{Race, labour and citizenship in international perspective}

A body of scholarship on white workers in the United States, emerging from the work of a new generation of labour historians in the 1990s, highlighted white working-class investment in republican citizenship amid black disenfranchisement. David Roediger's landmark 1991 book, The Wages of Whiteness, is representative of these scholars' approach which sees "white" itself as a racialised ideology, socially and historically constructed and hence in need of critical examination. Roediger, examining industrialising America in the period between the Revolution and the Civil War, tracks the ways in which white working-class identities took shape in this context marked by capitalist labour regimes, black enslavement and the revolutionary ideals of independence and freedom. White workers compensated for their anxieties about becoming dependent on wage labour by forming a self-image which brought together race, free labour and citizenship, framing themselves as the antithesis of the disenfranchised black slave. White working-class opposition to abolition, for instance, was therefore not simply a factor of anxieties surrounding potential job competition from emancipated slaves, but reflected a commitment to the equation of whiteness and citizenship. Roediger thus highlights 'the construction of identity through otherness' ${ }^{38}$ and encourages scholars to connect, rather than separate, race and class in considering identity formation and the dynamics 
of race relations. Jeremy Krikler's work on white working-class identity in early industrial South Africa, mentioned earlier, draws closely on Roediger. ${ }^{39}$

David Montgomery's Citizen Worker is also focused on antebellum America and shares the attention to white working-class agency evident in Roediger's work. With universal manhood suffrage preceding industrialisation in the USA, Montgomery investigates what advantages democracy and political rights provided workers in resisting the exploitative and restrictive aspects of emerging free market relations. Of course, political rights were the privilege of white men in this context - and while Montgomery notes that workers' claims to political rights and the equality of men were 'framed a nascent awareness of class conflict in the vocabulary of patriotism, race and rights', ${ }^{40}$ his analysis has little to say about race relations and the racialisation of working-class identity. Rather, its strength lies in examining working-class appeals to citizenship and rights as a response to the conflicts and tensions generated by capitalism, both inside and outside the workplace.

Appeals to citizenship were still a productive recourse a century later during the Great Depression, as Eric Meeks's work demonstrates. Examining the Arizona cotton industry between 1929 and 1945, Meeks shows how unemployment and poverty produced an influx of poor whites into low skill low wage jobs traditionally associated with Mexican labour. Resultant anxieties about these whites' ability to maintain their racial status saw the emergence of appeals to citizenship legitimising anti-immigration campaigns, as well as government support and employment favouritism for poor whites. This conflation of national identity with race was highlighted in cases where Mexican Americans were cast alongside immigrant Mexican workers as foreigners - indicating the importance not just of birthplace or political loyalty, but of race and culture. Arizona's 'white citizen workers' sought to distinguish themselves from Mexicans of similarly low socio-economic status by casting themselves as "good citizens", that is, independent men capable of providing for their families, and imagining Mexicans as lazy, dependent and unreliable. Such distinctions not only sought to mitigate class, race and gender anxieties, but also served to legitimate a broader racialised social order. ${ }^{41}$

Issues of citizenship have also recently attracted close attention in the field of African Studies, both in historical and contemporary perspective. Two edited volumes capture this well. Dorman et al. place the dynamic of 'making nations [and] creating strangers' central to analyses of the politics of nationalism and ethnicity shaping citizenship contestations in post-colonial Africa. In a context marked by economic distress, state failure or reconstruction, contestations over material resources such as land, opportunities or jobs are often 'potent and meaningful for their contestants because they are framed and understood in terms of identity and belonging'. ${ }^{42}$ The construction of citizenship as defining who is included in the body politic, the authors argue, is therefore necessarily entwined with processes of othering and exclusion - the creation of strangers. Most recently, Africanists have raised an argument against a narrow understanding of citizenship which invariably casts African colonial history 
in terms of a minority of citizens and a majority of subjects. This common dichotomy needs to be destabilised, they argue, by looking beyond merely formal legal definitions to everyday experiences and expressions in the engagement between people and the state. ${ }^{43}$ This may reveal how citizenship is more than a legal category, but a 'political condition that is constructed and contested by agential political subjects', ${ }^{44}$ revealing that 'there have always been different sorts of subjects'. ${ }^{45}$

Insights from this broader body of scholarship may be brought to bear productively on this investigation into white workers' response to the prospect of reforms to the race-based labour dispensation of late apartheid South Africa.

\section{Separate development: race and rights converge}

For the first two decades of its existence, the all-white SACLA was the NP's sweetheart labour confederation, supporting and enjoying the benefits of the government's racist labour policies. ${ }^{46}$ But in the course of the 1970s, the Confederation grew increasingly concerned about the threat that escalating economic and political challenges posed to white workers' interests. During his address at the Confederation's annual congress in June 1976, SACLA president Attie Nieuwoudt stated that white workers feared an 'onslaught' on their positions amid efforts to facilitate African advancement. ${ }^{47}$ Minister of Labour Fanie Botha, guest speaker at the congress, responded with the assurance that white workers would not lose their privileged position. Although some labour reforms were being planned, Botha reassured the Confederation's members that job reservation would be retained, and reaffirmed the established relations of mutual obligation binding politicians and white workers: 'Any developments in the future will be something we plan together', ${ }^{48}$ he promised.

The very next year, however, Botha appointed both an Industrial Tribunal, to report on the functionality of all existing job reservation determinations, and the Wiehahn Commission, to investigate the entire labour relations system. The Tribunal reported as the Commission was still finding its feet: 18 of the 25 job reservation determinations in force in 1976 were cancelled, and two suspended. Only five reservations remained in force - apparently where strong whites-only unions had been able to lobby for their retention. In the mining industry, for instance, both the Mineworkers' Union (MWU) and Underground Officials' Association (UOA) had argued against the removal of determination number 27. The UOA represented the 1,600 white workers responsible for the sampling, surveying and ventilation work reserved for whites by this determination, while the MWU's members, in the production side of mining, worked under these officials. ${ }^{49}$

Amid escalating local and international pressure for the abandonment of apartheid, these developments created a climate of expectancy and uncertainty ${ }^{50}$ For the white workers of SACLA, these reformist moves stood in stark contrast to established practices and Minister Botha's promises of continued white protection and partnership. Hence, as the Wiehahn Commission started 
its inquiry, it was perceived as a real moment in which the future shape of South Africa's labour dispensation was at stake.

SACLA's deputation before the Commission was led by its general secretary, Wessel Bornman of the South African Iron, Steel and Allied Industries Union. In addition to Bornman, the deputation included workers from the railways, public service and mining industry. A number of these unions also testified individually. The written submissions and oral testimony presented by SACLA and its affiliate unions were united around the retention of the existing race-based labour legislation. As the Commission's questioning returned time and again to the two most contentious issues characterising the apartheid labour dispensation - race-based job reservation, and the exclusion of African workers from the machinery of industrial conciliation through the denial of trade union rights - SACLA workers consistently based their arguments on the policy of separate development and its objective of creating black states separate from "white South Africa". SACLA workers drew a distinction between themselves, as citizens entitled to state protection and privilege in their own country, and Africans as "gasarbeiders" - guest workers or foreign labour temporarily employed in the Republic without any claim to rights or residence. White workers insisted that even Africans permanently residing in South Africa remained 'connected to their homelands' and hence foreigners who could not exercise rights in the Republic or insist on inclusion within its industrial conciliation machinery. ${ }^{51}$ This did not amount to discrimination, SACLA insisted, but accurately reflected separate development and the government's intended blueprint for the country's future. '[T] his is the ultimate goal in white South Africa, that no Bantu will have any right in South Africa', ${ }^{52}$ explained Arrie Paulus, general secretary of the MWU. Paulus pointed the commissioners to pronouncements in Parliament to support his claim: '[I]t was repeated [in Parliament] the other day that, once separate development has been fully implemented, there won't be a single Bantu that can claim South African citizenship', he stated, paraphrasing the minister of plural relations. The MWU was prepared to accept the full consequences of such a political dispensation:

I will go a step further, should a mine fall within a homeland, [. . .] that independent government makes its own laws, and if there should come a day when it decides to change its legislation so that a certain job becomes reserved for blacks, then I won't go argue that whites are being discriminated against, because it is their privilege to amend those laws. ${ }^{53}$

But in "our country", insisted Paulus, black workers remained outsiders without any claim to citizenship. ${ }^{54}$

This politics of inclusion and exclusion - framing themselves as citizens included in the body politic and blacks as outsiders with no claims to rights formed the foundation of SACLA workers' arguments against reform. When it came to the question of whether African trade unions should be legally recognised in South Africa, these white workers consistently called for the banning of 
African trade unions in the Republic: black workers could exercise their labour rights 'in their own country', and any efforts to organise in South Africa should be criminalised and prosecuted. ${ }^{55}$ One SACLA delegate demanded that African unions should be outlawed in South Africa because the country's political and legal arrangements should not be made subservient to employers' desire to negotiate with black workers. ${ }^{56}$ Similarly, when it came to the question of whether labour legislation should make provision for race-based job reservation, these workers again appealed to racial citizenship. The SACLA deputation stated that it considered job reservation a 'matter of the principle of the protection of interests ${ }^{57}$ and the 'self-preservation of the white worker in his own country'. ${ }^{58}$ The MWU, whose members had long benefitted from the reservation of blasting certificates for white miners, also forcefully defended job reservation, denying that it discriminated against black workers who were immigrants to 'white South Africa' with no claims to rights in the country. ${ }^{59}$ Bornman's metalworkers' union expressed similar convictions. It testified to receiving a mandate from its members to call for the state to give 'absolute preference to the utilisation of all available whites'. Thereafter, the state should prioritise matters of automation, and only then should it attend to the needs of "other" workers. ${ }^{60}$ It is clear that for these workers, neither the interests of capital, nor those of black workers, should take precedence over the interests of whites as citizens of the racial state. Given the reality of separate development, in which race and rights converged, this did not amount to discrimination but fulfilled the function of labour law and obligation of political elites in white South Africa of protecting citizen workers. ${ }^{61}$

Interestingly, white workers' rhetoric of inclusion and exclusion departed from the established racial logic of apartheid. For decades, opponents of trade union rights for black workers argued that Africans were not "ripe" - sufficiently mature, educated or civilised - to "handle" industrial citizenship. ${ }^{62}$ But by the late 1970s, white workers could no longer invoke this racial logic to oppose reform: representing black workers as unfit for labour or political rights would undermine the policy of separate development which sought to grant Africans independence in their own countries. While older ideas of black barbarism did occasionally crop up in some testimonies - the MWU characterised black mineworkers as 'from the bush' ${ }^{63}$ - these were few and far between. Rather, the centrality of separate development to white workers' defence of the racist labour dispensation meant that, for the most part, they were firmly committed to an understanding of blacks as citizens - but only outside "white South Africa". Such claims demonstrate the limits of apartheid's efforts to engineer a white majority in South Africa - white workers were clearly extremely aware of their minority status in the workplace.

\section{Class and racial citizenship}

During their testimony to the Commission, white workers outlined the dangers which removing protective legislation would pose to them as worker 
citizens. The SACLA deputation explained that job reservation offered protection from 'exploitation' ${ }^{64}$ arising from 'the capitalist businessman and his pursuit of maximum profit at minimum cost [which] will always seek out the cheapest labour' in the form of 'some other races' with 'lower living standards' ${ }^{65}$ For the MWU, too, protection was necessitated by the presence of a large cheap black labour force:

Employers have but one goal namely to secure ever greater profits. The easiest way to accomplish this is to make use of cheaper labour. The living standard of the non-white in South Africa is much lower than that of the white, making it easy to employ non-whites for lower remuneration. Should job reservation be removed, this will be to the advantage of the employer. ${ }^{66}$

Asked whether unions would be able to protect minorities, should job reservation be abrogated, SACLA's Bornman answered with a resounding 'no'. ${ }^{67}$ Crucially, therefore, these threats which white workers perceived were not in the first place racial, but capitalist in nature.

A further dimension of this was revealed during the testimony of Bornman's metalworkers' union in its own capacity. This deputation defended job reservation particularly on behalf of lesser-skilled economically vulnerable white workers:

As far as the job reservation determination is concerned [...] it is [protecting] specifically those people who do not have a trade that are rooted in these industries and who, should they leave, would be completely incapable of finding a similar income off [sic] their own accord anywhere else in the job market. ${ }^{68}$

This statement seems reminiscent of the policy of "civilised labour" - offering inflated wages and insulation from competition to white workers with relatively few skills. Indeed, the South African Iron, Steel and Allied Industries Union historically represented unskilled and semi-skilled white workers, many of whom were employed as production workers and operatives in the parastatal steel company Iscor, established in 1928. By 1976, this union represented some 38,000 workers across the industry. ${ }^{69}$ For them, job reservation concretised the state's responsibility to protect its citizens - particularly those who were vulnerable.

As a member of the Wiehahn Commission, SACLA president Attie Nieuwoudt also displayed concern with the economic vulnerability of some of the workers he represented, and their consequent dependence on statutory protection. This was tellingly demonstrated during a deliberation meeting on the Commission's draft Report when Nieuwoudt objected to references to poor whiteism in its historical overview of South Africa's labour legislation:

NIEUWOUDT: Mr Chairman, down here we refer to the poor white question, is it really necessary to mention this?

WIEHAHN: But this poor white question was part of our history, Mr Nieuwoudt. 
NIEUWOUDT: It can become part of [our] history again.

WIEHAHN: Sure, it can always become part of history and then other commissions in a hundred years can refer to it again.

NIEUWOUDT: Mr Chairman, it might be within ten months.

WIEHAHN: It is but history, Mr Nieuwoudt, simply a factual statement in historical interest. $^{70}$

The SACLA president knew that within the fold of his organisation, white poverty featured prominently in the historical consciousness of white workers particularly in older industries which had earlier in the century absorbed large numbers of unskilled and impoverished whites as "civilised labour". Indeed, Nieuwoudt's words show that the spectre of white poverty was perceived as a present reality. For SACLA workers, the prospect of labour reform suggested that the racial order could be reversed. This conjured up not just the prospect of job insecurity, but the very conditions of their class formation, which saw their whiteness and inclusion in the racial state offer them protection from the degradation of white poverty and the exploitation of capitalist employers. In this social order, it was their very citizenship which distinguished them from blacks and warranted their privileged position. Labour reform imperilled this.

In his study of white working-class identity in antebellum America, Roediger argues that racism was not just about economic position, but also about how white workers saw the world and themselves in it. In the case of late apartheid South Africa, white workers' opposition to reform clearly reflected their class interests and investment in the protection they enjoyed from capitalist exploitation. But it also reflected how they perceived the world and their position in it: they were whites, citizens, and therefore entitled to rights, while blacks were foreigners and had no claim to whites' country. This doctrine was not just their own; it was the official mantra of the South African government. For white workers, their class position rendered the rights and privileges of racial citizenship all the more precious, and the conditions of their class formation meant the distinction which racial citizenship drew between whites and blacks was fundamental to their identity and self-image. Recall Krikler's argument that white workers defined themselves in opposition to rightless, exploited and racially despised blacks. ${ }^{71}$ Reforming the county's race-based labour dispensation by granting Africans industrial rights would not only threaten white workers' job security, but their very self-image. Just weeks before the Wiehahn Commission released part one of its Report, MWU president Cor de Jager, speaking at the union's annual congress, expressed the fear that 'we [white workers] will become gasarbeiders in our own country'. ${ }^{72}$ White workers' anxieties around poor whiteism, exposure to capitalist exploitation, and of themselves becoming gasarbeiders all point to instances of their relegation to social positions historically and contemporarily associated with precarious whiteness, or blackness. More than just material and political implications, reform thus went to the heart of white working-class identity. Nic Wiehahn, in his exchange with Attie Nieuwoudt, seemed oblivious to this class dimensions of racial citizenship. He 
dismissed Nieuwoudt's objection as a matter of historical semantics, and did not register the much more fundamental, long-lived anxieties which it revealed.

\section{The politics of reform and the disruption of the moral economy}

In their testimony to the Wiehahn Commission, SACLA workers consistently emphasised that labour reform was not in the first instance an economic matter - it was a political one. The SACLA deputation insisted, for instance, that any issues around the employment conditions of African "guest workers" should be dealt with as matters of "interstate relations" - that is, addressed at a political level, between the government of South Africa and the relevant bantustans and employers involved. ${ }^{73}$ Later, when asked whether job reservation should be abolished, as this arrangement was detrimental to the national economy, the SACLA deputation responded that the economy was 'an entirely different matter ${ }^{74}$ - under discussion were matters of citizenship and political entitlement, rather than economic considerations. Recall, similarly, the metalworkers union's demand that the state make the utilisation of all available whites its first priority, followed by automation, and then 'the needs of others'. When this submission elicited an animated round of questioning regarding the state's responsibilities towards its coloured and Indian population, general secretary Bornman responded by stating that the testimony simply reflects existing government policy and the union's own priorities. 'We are not experts on the economy', he added. ${ }^{75}$ As with the view that African trade union rights were a matter of "interstate relations", this comment demonstrates how white workers regarded labour policy as a political rather than an economic issue. And as far as SACLA workers were concerned, the political arrangements of separate development should be replicated in all spheres of life, including labour arrangements, irrespective of economic imperatives.

By continuously asserting their position as citizens of the racial state, appealing to the policy of separate development, and repudiating efforts to represent labour reform as a primarily economic issue, these white workers were resisting the depoliticising thrust of the reform process. When the MWU deputation was asked to consider alternative measures which might replace statutory protection, Paulus refused to participate in such efforts to depoliticise the matter. Alternative measures would still amount to job reservation and therefore still attract the ire of the international community. It would be much better for South Africa to 'call a spade a spade' and defy the foreign opinion, which has 'no business here' ${ }^{76}$ Paulus and the workers he represented accepted that the maintenance of racial citizenship would have political ramifications, and found these to be preferable to the alternative. Claims to white workers' entitlement and belonging to the white body politic reflected their insistence that the existing practices of obligation and reciprocity between different parties in this body politic be upheld.

The fundamental entanglement of labour and politics meant that these workers' testimonies highlighted the contradiction inherent in attempts at labour 
reforms, namely that African workers could be granted industrial without political citizenship. Indeed, white workers in the SACLA fold were the only group to impress upon the Commission the potential political ramifications of this strategy: granting industrial rights to Africans would be the thin end of the wedge and offer Africans avenues for demanding and seizing full citizenship. This was expressed most clearly by SACLA president Nieuwoudt. As a member of the Wiehahn Commission, Nieuwoudt echoed his confederation's views, similarly stressing that labour matters and potential reforms functioned within a broader political context and had to adhere to official state policy. Already at the outset of the inquiry, he had stated his commitment to this social order, ${ }^{77}$ and throughout the investigation, he was unwilling to debate any measures deviating from it. ${ }^{78}$ In the closed deliberation meetings following the Commission's testimony hearings, we find Nieuwoudt continually defending his commitment to job reservation for 'the white worker in his own country' and the denial of union rights for African workers in the Republic as arrangements which South Africa's policy of separate development demanded:

[M]y Prime Minister [Vorster], who is now retired, had me in his office where I had a long conversation with him and he explained everything very clearly. Mr Chairman, he said that the black man would get his own republic where he would be master and have the vote and where he could govern in the way that the world wishes him to govern, as a sovereign nation. ${ }^{79}$

For Nieuwoudt and the workers he represented, labour went hand in hand with matters of political power and citizenship so that rights and privilege in the industrial sphere could not be divorced from rights and privilege in the political sphere. By pointing to Africans' imminent "mastery" in their own countries, Nieuwoudt's statement suggests his anxiety about the implications for white rule in South Africa, should Africans be granted labour rights. Thus, as the Commission's deliberation meetings continued, Nieuwoudt continually and urgently directed his fellow commissioners' attention to the potential political ramifications of labour reform: on one occasion he implored them to consider 'where are we going with this fatherland of ours' $;{ }^{80}$ on another, he warned that 'we are busy deciding about the future of South Africa here, because the labour force will determine our direction, and politics will just have to follow suit'. ${ }^{81}$ These same concerns underlay SACLA unions' insistence on the political nature of reform and its consequences. The South African Iron, Steel and Allied Industries Union even concluded its testimony by drawing the Commission's attention to the role of black unions in the liberation struggle of various African countries. ${ }^{82}$ White workers recognised and warned that labour reform would mark the beginning of the end for the racial state. Many years later, Wiehahn commissioners drawn from academic and business circles admitted that white workers had been much more attuned to the possible political ramifications of labour reform than commissioners from other social spheres ${ }^{83}$ 
It is unsurprising that white workers would have been most sensitive to the possible ramifications of reform. Industrial citizenship for Africans called the established convergence between race and rights into question - if blacks could be given rights, whites could have them taken away. This understanding is evident throughout SACLA workers' testimony to the Commission: they did not see potential reforms as awarding black workers rights alongside white workers, but as blacks gaining rights at the expense of white workers. For white workers, the uncoupling of race from rights implied the potential of exclusion from racial citizenship. To be sure, there were no indications that the political system was going to change fundamentally and overall white rule was set to continue in South Africa. For white workers, the prospect of labour reform therefore placed both their position of economic vulnerability as well as their identities as citizen workers at risk in a context in which other whites would retain their privileges within the racial state. Hence it was this citizenship to which they appealed unceasingly. Towards the end of the metalworkers' union's testimony, chairman Wiehahn posed a final question:

WIEHAHN: But suppose there would be overwhelming evidence in a different direction [to that presented by the union, for the retention of a race- based labour dispensation], do you expect your union's views to be decisive, or do you expect the Commission to simply take cognisance of your union's views? [. . . I would just like to know your general view on the matter.

BORNMAN: Mr Chairman, I suppose every person would like to see his views upheld, and this is the case for us also. If we should be in the minority on the issue - PAUSE

WIEHAHN: Not that this would necessarily be the case. BORNMAN: We have always been good citizens. ${ }^{84}$

These statements concluded the session. Confronted with the real prospect that white workers might lose their privileged position, Bornman appealed to the established moral economy. He implored the Commission, as proxy for the state and the political elite, to consider the political loyalty and industrial discipline white workers had shown the National Party, their role in maintaining the key pillars of a racially ordered society and bolstering white power in South Africa - this, in exchange for state support and protection of their position as part of this racial order. White workers had 'always been good citizens', Bornman reminded the Commission, and this relationship had to be honoured.

But the government had other plans. Shortly after the Commission released its first report, the NP accepted recommendations to scrap job reservation and legalise African unions. In a revealing statement which echoed Bornman's appeal, MWU general secretary Paulus lambasted the government for betraying white workers: 'in accepting the Wiehahn report, the government has committed the greatest act of treason against the white workers of South Africa since 1922, when hundreds of miners were shot because they rebelled against the Chamber of Mines' efforts to force them to share their work with blacks' ${ }^{85}$ For 
the MWU, reforms thus recalled earlier struggles for recognition, protection and status as white citizens in the racial state. The state had withdrawn its support for working-class whiteness.

\section{Rethinking reform}

Of course, as indicated earlier, not all sections of the organised labour movement sought the maintenance of the apartheid labour dispensation. The multiracial labour federation TUCSA claimed to welcome moves towards reform - although the Council suffered from a great deal of internal division on the subject. Overall, its leadership took a reformist stance, supporting the removal of discriminatory legislation and the granting of trade union rights to Africans, subject to strict state regulation. TUCSA representatives did not draw the same links between labour rights and citizenship as their SACLA counterparts, and generally echoed the depoliticising rhetoric of reformist politicians. ${ }^{86}$ It has been suggested that TUCSA was hoping to incorporate African workers into its structures, thereby gaining control over African unionism in this way instead of through legislative means, as SACLA wanted. ${ }^{87}$

This different strategy may be ascribed to the different kinds of workers represented by the two federations. Not only did SACLA represent far more whites than TUCSA, but its members also 'owed their privilege - sometimes their very jobs - to direct government intervention. It was strongest either on the railways and in state-owned steel plants, which were created partially to offer whites protected jobs, or on the mines where white workers relied on job bars in the law to bolster their privilege. Its members had no skilled trade to protect them' ${ }^{88}$

SACLA workers' resistance to reform, as articulated in the course of the Wiehahn inquiry, provides new insights which challenge existing understandings of reform-era South Africa. Scholars regard late apartheid reforms as part of a "scheme" to remodel the foundations of white supremacy - yet it clearly did not enjoy the support of all whites. The scheme's new politics of inclusion and exclusion threatened white workers' position and identity as citizens of the racial state. Indeed, if reform constituted a redefinition or reimagining of the status of urban Africans, as Ashforth argues, it follows that this would also entail the redefinition of the status of white workers whose very position relied on the exclusion of Africans from the privileges of industrial citizenship, and whose identity was intimately bound up with the rightlessness of blacks. Reform heralded the start of the withdrawal of state support for working-class whiteness. As a "scheme" to 'share power without losing control', it did not include white workers. Moreover, in the context of economic and political crisis and the shifting priorities of capital and the state, this "scheme" instigated the destruction of the established moral economy.

This alerts us to the class conflicts produced within white society by the political challenges and shifting capitalist imperatives of the late apartheid period. Existing scholarship is mainly focused on the tensions between the white state 
and the black populace. And while scholars recognise that by the 1970s the NP's priorities had drifted away from its original agricultural and working-class support base towards middle-class suburbanites and business interests, ${ }^{89}$ little sustained attention has been paid to the intra-white class conflicts and implications of this historical juncture. Contestations around inclusion and exclusion evident in SACLA workers' testimony to the Wiehahn Commission therefore point us towards previously overlooked dynamics of the politics of reform and the process of state remaking and status renegotiation it entailed. Scholars have suggested that by the 1970 s, whites no longer needed a racially discriminatory framework to maintain their privileged position..$^{90}$ Yet SACLA workers' reactions to the prospect of reform during the Wiehahn process reveal the continued importance of racial privilege and protection to a substantial part of the white working class. By pointing to capitalist exploitation, the economic vulnerability of lesser-skilled whites and the threat of white poverty, white workers demanded continued state protection. Their commitment to separate development and their anxieties about reform reducing them to gasarbeiders expressed very different priorities to those pursued by the white state and business leaders. Historians therefore need to reconsider their understandings of white interests in the late apartheid period to include the continued importance of whiteness to subaltern whites.

In considering the entanglement of race, labour and citizenship in late apartheid South Africa, white workers' response to the prospect of reform reveals how class position impacts citizenship. Hunter, commenting on the misleading notion of a minority of citizens versus a majority of subjects in understandings of African colonial history, points out that 'there have always been different sorts of subjects' ${ }^{91}$ - and, as this chapter shows, different sorts of citizens.

\section{Notes}

1 Lodge, 'Resistance and Reform', 409-491.

2 Lodge, 'Resistance and Reform'; Worden, The Making of Modern South Africa, 128-130, 132-136.

3 Department of Labour and of Mines, Report of the Commission of Inquiry into Labour Legislation Part 1 (Key Issues). Pretoria: Government Printer, RP49/1979, v.

4 Coupe, 'Labour Relations by Authoritarian Regimes Since 1945', 14.

5 Friedman, Building Tomorrow Today, 155.

6 Industrial sociologists and labour historians invoke the idea of 'industrial citizenship' to refer to workers' rights to industrial representation and participation in the structures of industrial conciliation - including forming and joining trade unions, electing representatives to those organisations, and engaging in actions such as negotiations and strikes in pursuit of better employment conditions. On industrial citizenship for Africans in the context of reform-era South Africa, see Barchiesi, Precarious Liberation, 51; Lichtenstein, 'A Measure of Democracy', 113-138.

7 Friedman, Building Tomorrow Today, 156-158; Lodge, 'Resistance and Reform', 425, 437, 443-444; Giliomee, The Last Afrikaner Leaders, 147; Greenberg, Legitimating the Illegitimate.

8 Saul and Bond, South Africa The Present as History, 112.

9 Dubow, Apartheid, 297.

10 Giliomee, The Last Afrikaner Leaders, 139, 147. 
11 Posel, 'Language, Legitimation and Control'.

12 Ashforth, The Politics of Official Discourse.

13 Cooper, Decolonization and African Society, 266.

14 Ibid.

15 Lodge, 'Resistance and Reform', 454.

16 Giliomee, The Last Afrikaner Leaders, 161.

17 South African Institute of Race Relations (SAIRR), A Survey of Race Relations in South Africa 1970, 81, 126.

18 Compared to 41\% in 1946 and 29\% in 1991. Sadie, The Fall and Rise of the Afrikaner, 54.

19 Marks, 'Class, Culture, and Consciousness', 126, 132, 136.

20 Krikler, The Rand Revolt, 149; see also Johnstone, Class, Race and Gold.

21 See for instance Yudelman, The Emergence of Modern South Africa; Hyslop, 'The Imperial Working Class Makes Itself "White"; Krikler, The Rand Revolt; Katz, 'White Workers' Grievances and the Industrial Colour Bar'; Katz, A Trade Union Aristocracy.

22 Horrell, South Africa's Workers, 2-3; Feinstein, An Economic History of South Africa, 86-87.

23 Moral economy describes 'those elements of culture (customs, beliefs, and practices) that normatively regulate and legitimize the [unequal] distribution of resources such as wealth, power and honour or status in society'. It was developed in the work of E.P. Thompson and James Scott respectively as an analytical tool for analysing the relations between dominant and subordinate classes, particularly as revealed in the behaviour of the latter, caught in the transformation of one social order to another - from peasant to industrial, capitalist market economies, from pre-colonial societies to modern colonial states. Its most prominent proponents in the African context have been John Lonsdale and Bruce Berman. Berman, Laliberté and Larin, The Moral Economies of Ethnic and Nationalist Claims, 4; Thompson, The Making of the English Working Class; Scott, The Moral Economy of the Peasant; Berman and Lonsdale, Unhappy Valley; Lonsdale, 'Moral Ethnicity and Political Tribalism'.

24 O'Meara, Volkskapitalisme, 65-68, 103, 108; O’Meara, Forty Lost Years, 42, 54-57, 77-80. See also Adam and Giliomee, Ethnic Power Mobilized; Giliomee, 'Constructing Afrikaner Nationalism'.

25 Witz, 'A Case of Schizophrenia'.

26 Feinstein, An Economic History, 50; Horrell, South Africa's Workers, 16.

27 Visser, 'From MWU to Solidarity', 22.

28 The policy had its roots in the Afrikaner Nationalist belief in the distinctiveness of individual nations and their resultant right to self-determinations, as well as its commitment to Western civilisation and the maintenance of white privilege and exclusivity. See Posel, 'The Apartheid Project'; O'Meara, Forty Lost Years; Dubow, Apartheid.

29 Quoted in Giliomee, The Last Afrikaner Leaders, 76.

30 Ibid., 44, 76, 81.

31 Dubow, Apartheid, 105.

32 Giliomee, The Last Afrikaner Leaders, 89, 90, 100-101; Davenport, South Africa, 301; Dubow, Apartheid, 153.

33 Quoted in Giliomee, The Last Afrikaner Leaders, 90-91.

34 Dorman, Hammett and Nugent, Making Nations, Creating Strangers, 13.

35 Horrell, South Africa's Workers, 19-20, 30, 39; Friedman, Building Tomorrow Today, 73; Greenberg, Race and State in Capitalist Development, 296, 300-301.

36 For SACLA see South African Institute of Race Relations, A Survey of Race Relations in South Africa 1976, 313; South African Institute of Race Relations, A Survey of Race Relations in South Africa 1977, 288. For TUCSA, see South African National Archives of South Africa (hereafter NASA), K364, Volume 33, AK 6/3/1/1/4 Volume II, Documentation accompanying letter from Industrial Registrar to The Secretary, Commission of Inquiry into Labour Legislation, 10 July 1978, 1-3; NASA, K364, Volume 33 AK 6/3/1/1/4 Volume II: 'Memorandum concerning a sound labour relations system, 
submitted by the Trade Union Council of South Africa to the Commission of Inquiry into Labour Legislation, October 1977' (Memorandum Dokument No. 00147), 1.

37 The Wiehahn Commission's collection is held at the National Archives of South Africa in Pretoria. In addition, Naas Steenkamp - the only surviving Wiehahn commissioner at the time of this research - preserves a private archive at his home outside Cape Town. This private collection largely corresponds to that of the National Archives. I consulted both collections for the purpose of this research. They are variously referenced as NASA or SA/WD (Steenkamp Archive/Wiehahn Documentation) here.

38 Roediger, The Wages of Whiteness, 14.

39 Krikler, The Rand Revolt, 149.

40 Montgomery, Citizen Worker, 6.

41 Meeks, 'Protecting the "White Citizen Worker"'. See also Meeks, Border Citizens.

42 Dorman, Hammett and Nugent, Making Nations, Creating Strangers, 6.

43 Hunter, 'Introduction', 1-2, 4; See also Russell, 'Burundi, 1960-67'.

44 Balaton-Chrimes, 'The Nubians of Kenya', 167.

45 Hunter, 'Introduction', 1-2.

46 Friedman, Building Tomorrow Today, 72-73.

47 SAIRR, A Survey of Race Relations in South Africa 1977, 316.

48 Quoted in SAIRR, A Survey of Race Relations in South Africa 1976, 314.

49 SAIRR, A Survey of Race Relations in South Africa 1977, 226-227.

50 Friedman, Building Tomorrow Today, 151.

51 SA/WD, Testimony Meeting 8, Pretoria, 6 December 1977, 913, 914, 919-921; also Testimony Meeting 9, Pretoria, 7 December 1977, 1018; Testimony Meeting 24, Johannesburg, 22 February 1978, 3692-3693, 3699-3700, 3718-3719.

52 SA/WD, Testimony Meeting 24, Johannesburg, 22 February 1978, 3699.

53 Ibid., 3700.

54 Ibid., 3719; also Testimony Meeting 9, Pretoria, 7 December 1977, 1005.

55 SA/WD, Testimony Meeting 24, Johannesburg, 22 February 1978, 3716; also Testimony Meeting 8, Pretoria, 6 December 1977, 93; Testimony Meeting 8, Pretoria, 6 December $1977,924$.

56 SA/WD, Testimony Meeting 8, Pretoria, 6 December 1977, 925.

57 Ibid., 908.

58 Letter from SACLA to the Wiehahn Commission, dated 12 May 1978, quoted in SA/ WD, Deliberation Meeting 43, Pretoria, 5 September 1978, 7240.

59 SA/WD, Testimony Meeting 24, Johannesburg, 22 February 1978, 3699.

60 SA/WD, Testimony Meeting 9, Pretoria, 7 December 1977, 995.

61 SA/WD, Testimony Meeting 8, Pretoria, 6 December 1977, 923.

62 Lichtenstein, 'A Measure of Democracy'.

63 SA/WD, Testimony Meeting 24, Johannesburg, 22 February 1978, 3701.

64 SA/WD, Testimony Meeting 8, Pretoria, 6 December 1977, 909.

65 NASA, K364, Volume 33 AK 6/3/1/1/4 Volume II: SA Confederation of Labour (Memorandum Dokument No. 00164), 1; also SA/WD, Testimony Meeting 8, Pretoria, 6 December 1977, 909.

66 NASA, K364,Volume 33 AK 6/3/1/1/4 Volume II: '[MWU] Memorandum in verband met Arbeidswetgewing' (Memorandum Dokument No. 00182), 2; also SA/WD, Testimony Meeting 24, Johannesburg, 22 February 1978, 3716-3717.

67 SA/WD, Testimony Meeting 8, Pretoria, 6 December 1977, 923.

68 SA/WD, Testimony Meeting 9, Pretoria, 7 December 1977, 1004.

69 Lewis, Industrialization and Trade Union Organization, 78-83.

70 SA/WD, Deliberation Meeting 52, Pretoria, 27 November 1978, 8771-8772.

71 Krikler, The Rand Revolt, 149.

72 'Cor de Jager praat kaalkop oor inflasie en gooi MWU se deure wyd-oop', The Mineworker, 7 February 1979, 3-4. 


\section{Danelle van Zyl-Hermann}

73 SA/WD, Testimony Meeting 8, Pretoria, 6 December 1977, 925; also Testimony Meeting 24, Johannesburg, 22 February 1978, 3693, 3712.

74 SA/WD, Testimony Meeting 8, Pretoria, 6 December 1977, 918.

75 SA/WD, Testimony Meeting 9, Pretoria, 7 December 1977, 995, 1002-1003.

76 SA/WD, Testimony Meeting 24, Johannesburg, 22 February 1978, 3717.

77 Department of Labour and of Mines, Report Part 1, 4.

78 See for example SA/WD, Deliberation Meeting 46, Pretoria, 8 September 1978, 7781; Deliberation Meeting 50, Pretoria, 24 October 1978, 8364, 8485, 8539, 8549; Deliberation Meeting 54, Pretoria, 11 December 1978, 9029.

79 SA/WD, Deliberation Meeting 47, Pretoria, 26 September 1978, 8028.

80 Ibid.

81 SA/WD, Deliberation Meeting 54, Pretoria, 11 December 1978, 8987.

82 SA/WD, Testimony Meeting 9, Pretoria, 7 December 1977, 1020-1021.

83 Piet van der Merwe interviewed by Naas Steenkamp, Pretoria, 7 October 2008. Also see Piet van der Merwe interviewed by Hermann Giliomee, Pretoria, 18 March 2009.

84 SA/WD, Testimony Meeting 9, Pretoria, 7 December 1977, 1019-1020. The emphasis and PAUSE are recorded in the original.

85 Paulus 'Grootste verraad teenoor blanke werkers!', The Mineworker, 16 May 1979, 1.

86 TUCSA's testimony is contained in SA/WD, Testimony Meeting 22, Johannesburg, 20 February 1978, 3215-3287, and NASA, K364, Volume 33 AK 6/3/1/1/4 Volume II: 'Memorandum concerning a sound labour relations system, submitted by the Trade Union Council of South Africa to the Commission of Inquiry into Labour Legislation, October 1977' (Memorandum Dokument No. 00147). For a full analysis of TUCSA's position, see Van Zyl-Hermann, 'White Workers and South Africa's Democratic Transition', 75-83.

87 Friedman, Building Tomorrow Today, 75.

88 Ibid., 76.

89 O'Meara, Forty Lost Years, 78-79, 120, 139-140; Terreblanche, Lost in Transformation? 54.

90 Giliomee, 'Apartheid: A Complex Heritage'; Mariotti, 'Labour Markets During Apartheid in South Africa', 120.

91 Hunter, 'Introduction', 1-2. 